cought. But modiflcations of this kind cannot be discussed in this paper, and must be left to the individual himmelf to work out.

[Copies of this paper with, if desired, the table mounted on card, may be obtained from Dr. Henderson Smith, Lister Institute, Chelces Gardens, London, S.W.]

\section{The Cramian Tertures}

\author{
os
}

\section{TRYPANOSOMES CAUSING DISEASE IN MAN AND DOMESTIC ANIMALS IN CENTRAI. AFRICA.}

Dehivered before the Royal College of Physicians OF LONDON,

By SIR DAVID BRUCE, C.B., F.R.C.P., F.R.S.,

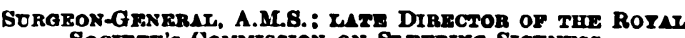
Soctret's Commisaion oN BLEEPINa BICENEss.

\section{LECTURE II.-Glossina Morsitans: Trypanosoma Brocer : Wild Game.}

Is my first lecture an attempt was made to introduce the subject-the trypanosome diseases of man and domestic animals in Central Africa-by a fow introductory remarks on trypanosomes generally, and their classification; and also by a short description of their carriers, the tsetse flies. In this lecture I propose to deal with one of the species of trypanosomes more in detail, describing its morphology, its pathogenic action on various animals, its carrier-the tsetse fly, Glossina morsitans-and the reservoir of the virusthe wild game.

TRYPANOSOMA BRUCEI.

The first species of Group A is Trypanosomza brucei, and it will be convenient to begin with it, as it is also first chronologically. That is to say, it was the first pathogenic trypanosome discovered in Central or South Africa, and if you will allow a short autobio. graphical digres. gion, I shall relate the circumstances leading up to the discovery.

\section{Investigations in $1894-96$.}

Shortly after I arrived in South Africa in 1894, the late Sir Walter Hely. Hutchinson, the then Governor of Natal and High Commissioner of Zululand, asked me to go to the north of Zululand in order

to report on an outbreak of disesse, called nagana, which had broken out among the native cattle.

Travelling at that time was no easy matter, as the rail. way into Zululand had not been constructed. My wife and I left Pietermaritzburg on October 27th, 1894, going by mule wagon; we arrived seven days later in Eshowe, the capital of Zululand. There an ox wagon was provided, and in it we trekked to Ubombo, a magistracy in the north of Zululand, and in the centre of the affected district. This was reached, after a month's journey, on November 24th, 1894.

Fig. 1 represents the small wattle and daub hut which was provided for living in. The verandals was used at finst as the laboratory, but afterwards, with the aid of the natives, a special hut was built. Shortly after we arrived some of the affected cattle were brought in by the natives. As I had just come from the Army Medical College, Netley, where I had boen teaching bacteriology for tive years, it was natural that a bacteriological exanination of the blood and organs of the infected cattle should first be made. This proved negative.

About this time (1894) the study of the blood had become popular, thanks probably in great measure to Ehrlich, and it was the fashion to make elaborate examinations of the red and white blood corpuscles. 'To this the discovery of the nagana parasite was probably due. It must be remembered that these parasites are, as a rule, very few and far between in the blood of oxen, and also that our staining methods in those days were rather primitive. After some days of this blood examination it began to be remarked that a curiously-shaped object, different from anything previously found in blood, was sometimes seen lying among the blood corpuscles. At first it was thought to be accidental, due to the carbol-fuchsin stain which was being used, but soon it became evident that it might be a blood parasite. It was then thought that if it was it might be motile in the living state. Fresh preparations of blood were made, and after a long search a rapidly moving object was seen lashing about among the red blood corpuscles. At that time I knew nothing about trypanosomes, and at first thought that the wriggling object might possibly be a small filaria. There were few or no allusions to these haematozoa in medical literature at that time, but when I returned to Natal and had an opportunity of consulting books it soon became evident that the rapidly vibrating body was probably a trypanosome.

But there was as yet no proof that the organisms seen had any causal connexion with the disease. They might well be harmless blood parasites, and they were so scanty in numbers in the blood of the oxen that this might well be so. This led to trying the effect of injecting the blood of nagana cattle into horses and dogs. In these animals the disease is much more acute than in cattle, and the blood swarms with the parasites. In this way it began to be evident that these haematozoa had a causal connexion with the disease.

But at that time. there was no suspicion that nagans. and tsetse-fly disease were one and the same. It was beliered by everybody that the tsetse fly killed horses and cattle by injecting a poison into them. Moreover, these cases of nagan were occurring among native cattle many miles away from the "fly belt." The work was being done on the top of the Lebombo, a range of hills some $2,000 \mathrm{ft}$. in height, running north and south, about 50 or 60 miles from the coast. Between the hills and the ses there was a low-lying coast plain, some parts of which were infested with tsetse flies. Now, I had read in Livingstone and other African travellers and hunters about the tsetse-fly disease, and was curious to know what it was like. Two young oxen and several dogs were therefore sent down into this "fly belt" and herded among the fly for a fortnight. At the end of this time they were brought back to the hill, and it was a great surprise to find the same parasites in their blood as that found in the nagana oxen. In this way the fact gradually unfolded itself that nagana and the "fly disease" of the travellers and hunters were identical. This, then, was the manner in which the discovery of the part played by trypanosomes in tsetse-fly disease was made.

I arrived at Ubombo on Norember 24th, 1894, and was. 


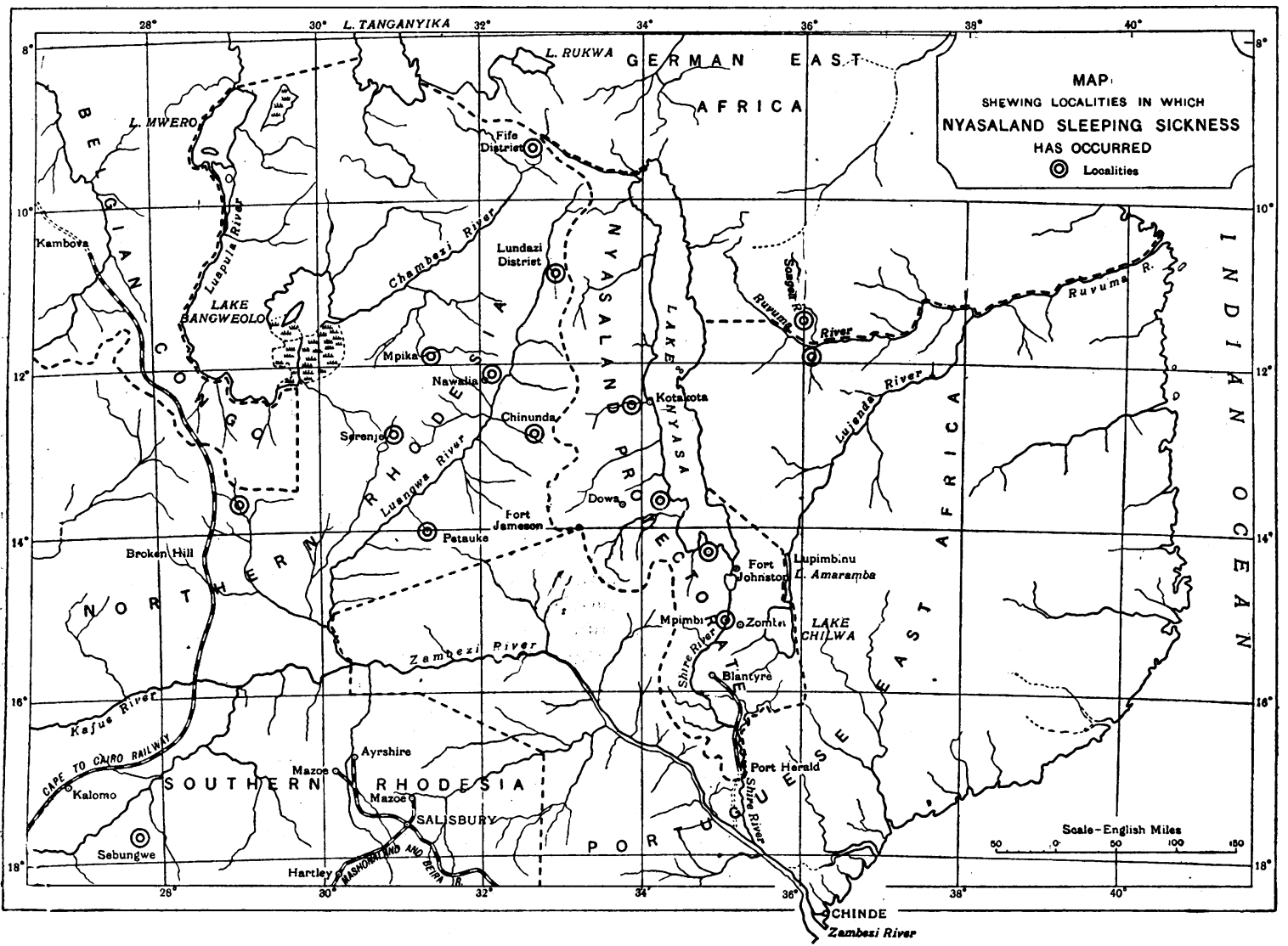

recalled to duty in Natal two months afterwards, on January 26th, 1895. This was done by the military authorities in South Africa, who evidently thought they had not been sufficiently consulted in the matter of this investigation in Zululand. It was a year before the Governor could obtain from England the authority of the Seoretary of State to enable me to return along the long road, and take up the broken investigation. I mention this to show that if it had not been for the energy and determination of the Governor of Natal, the Hon. Sir Walter Hely-Hutchinson, this discovery might have been delayed for years. The initiation of the inquiry into the nature of nagana was wholly due to him. In spite of much difficulty and obstruction he persevered in the furtherance of the investigation, and certainly without his active aid nothing at that time would have been accomplished.

The nagana parasite was, in 1896, sent in the living condition to the Royal Society in London, when it was placed in the liands of Messrs. Kanthack, Durham, and Blandford. Their investigation lasted two years, and was published in the Proceedings of the Royal Society in 1898. In that year the trypanosome was handed over to Bradford and Plimmer at the Brown Institution, and described and named by them in a paper written in 1899. At this time the nagana parasite found its way into many laboratories and much of the earlier work on trypanosomes was founded upon it.

Nyasaland Sleeping Sickness.

A new and very important page in the history of this haematozoon was turned in February, 1910, when Professor Stephens, of the Liverpool School of Tropical Medicine, while examining in class work a stained specimen of rat's blood, containing what was supposed to be Trypanosoma gambiense-that is, the trypanosome of ordinary sleeping sickness-noticed a marked peculiarity in the morphology. This made him doubt whether the micro-organism was really Trypanosoma gambiense or not. These parasites were obtained from a man, under treat. ment in Liverpool, who had been infected in North-East Rhodesia in September, 1909

Stephens, in collaboration with Fantham, then studie this organism more closely, and came to the conclusion that it was a different species from Trypanosoma gambiense, and called it Trypanosoma rhodesiense.

In this way, then, came about the separation of the Nyasaland form of sleeping sickness from the old Congo form, and you will agree with me that the greatest credit is due to these gentlemen for being the first to bring this far-reaching and important discovery to light.

The Commission of 1911.

In 1911 a Commission was sent to Nyasaland by the Colonial Office, under the direction of the Royal Society, to inquire into this and other questions of a like nature.

The Commission came to the same conclusion as Stephens and Fantham-that Nyasaland sleeping sickness and Congo sleeping sickness are separate and distinct diseases. . We were, however, soon struck by the fact that although the fly country of Nyasaland extends almost uninterruptedly into the Zululand fly countrv, no nagana trypanosomes-the common trypanosome of wild game in this part of Africa-could be found. Everywhere, in the wild tsetse flies and in the wild game, it was always Trypanosoma rhodesiense, and this in spite of the fact that nagana was reported from Portuguese East Africa, German East Africa, and in fact all round about except Nyasaland. It then began to dawn on the mind of the Commission that perhaps Trypanosoma rhodesiense was in reality the old nagana parasite masquerading under a new name. As soon as possible a strain of the latter was procured from Zululand for purposes of comparison, and the Commission, after a good deal of work, came to the conclusion that the nagana parasite and Trypanosoma rhodesiense are in reality one and the same. They are identical in morphology, in their action on animals, and in their manner of development in the tsetse fly, and until further proof is brought forward that they are separate species the Commission decided to consider them as identical.

This is a very important matter, because if Trypanosoma brucei and Trypanosoma rhodesiense are identical, then we may expect to find cases of "Nyasaland sleeping sickness" cropping up in all parts of Africa where nagana occurs-in the Sudan, Uganda, British East Africa, NorthEastern Transvaal, and Zululand.

If, on the other hand, they are separate species, then cases of this disease would only be expected to occur 
where Trypanosoma rhodesiense is found in addition to nagana. In the past nagana has always been regarded as harmless to man, and certainly no harm seemed to

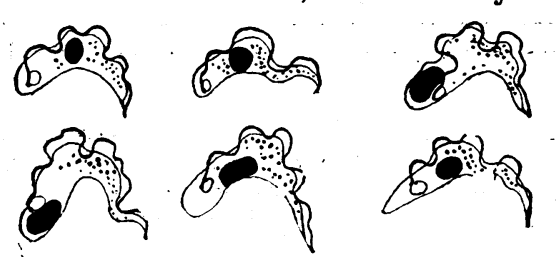
come to . those who lived or travelled in " flly country." To this it may be an. swered that it is only within recent years that microscopical examination of the

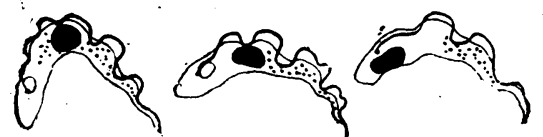

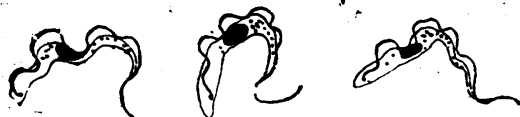
blood of such cases has been made. Many cases of death occurred among hunters and ex. plorers which were usually put down to malaria, but it is possible some of these may have been due to infection Fis. 2.-Tryyanosoma brucei; Zululand, 1913. by nagana. This
is a question
which $F$ will not pursue further; time and further know. Fis. 2.-Trypanosoma brucei; Zululand, 1913. by nagana. This
which $\mathrm{F}$ will not pursue further; time and further knowwhich $\mathbf{F}$ will not pursue further; time and further knowcan be given. But it must be understood that in the can be given. But it must be understood that in the rhodesiense is included.

So much for the history of the nagana parasite. Let us now consider the distribution of thiis trypanosome in Africa.

Geographical Distribution of Trypanosoma brucei.

The distribution of the nagana parasite, Trypanosoma brucei, in Africa, is shown in the map published to illus.

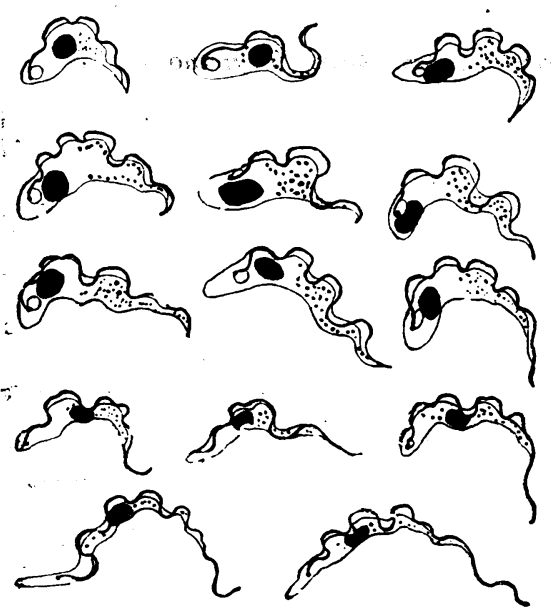
trate my first lecture (p. 1074). It will be seen that Trypanos oma brucei and the disease caused by it-nagana-are widely distri. buted in Africa, extending from the sudan to Zululand, and from the Gambia to Zanzibar ; in fact, it is the most widely dis. tributed patho. genic trypano. some in Africa.

It may be that in the future strains of nagana in widely separated parts of

Fig. 3.-Trupanosoma brucei; huma strain; Nyasaland. Africa may be found to differ from each other sufficiently
to enable them to be ranked as separate species. As to enable them to be ranked as separate species. As named Trypanosoma togolense, and that of Uganda Trypanosoma ugandae. But until more is known of these varieties $I$ think it better for the sake of simplicity to include them all under one specific term.

In the map here given (p. 6) the districts of Central Africa are shown in which up to the present cases of this disease in man have been discovered.

Morphology of Trypanosoma brucei.

The Zululand strain of Trypanosoma brucei we had sent to us in Nyasaland in 1913 from Pretoria, in order to compare it with the Nyasaland human strain-the Trypano. soma rhodesiense of Stephens and Fantham-is shown in Fig. 2. This trypanosome is dimorphic or polymorphic. This merely means that between the shorter and longer forms a greater diversity of shape is found than in the species belonging to the other groups. The short forms are broad and stumpy in appearance, and have no free flagellum, whereas the long are much more slender in appearance, and have a well-marked free flagellum.

In the living and unstained preparations this dimorphic character can be readily made out, and the parasites are seen to be activeiy motile, although they do not move far from one place, they have little or no power of translation. The long and slender are very similar in shape and appearance to Trypanosoma gambiense, $\cdot \mathrm{but}$ the short forms have of te n broader and blunter ends.

In well stained specimens the
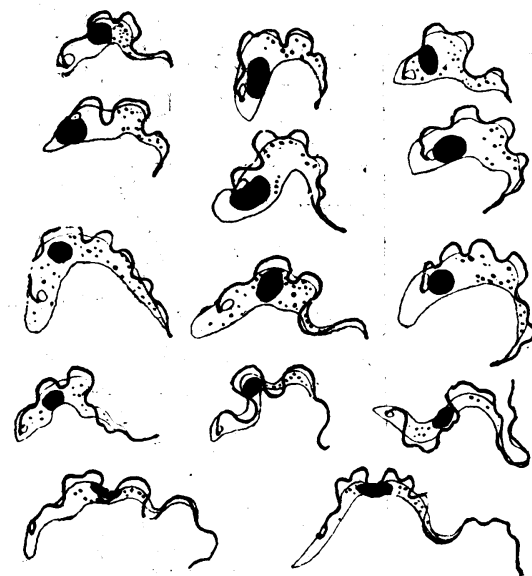

Fig. 4.-Trypancsoma brucei; Zululand, 1894 protoplasm of many of the trypanosomes shows granules especially in the anterior portion of the cell. The nucleus is oval in the long and slender, and round or oval in the short and stumpy. One peculiarity about the nucleus of this species is that it is frequently placed far back in the body of the organism. This peculiarity is only found in the sliort forms, never in the long. The percentage of these so-called posterior nuclear forms is often large-even as high as 50 per cent. The micronucleus is small and round, and situated on an average 2 microns from the posterior extrernity in the long and slender forms and 1.4 microns in the short and stumpy. The undulating membrane is well developed and thrown into bold folds and undulations.

The flagellum in the long and slender a ver. ages 5.8 microns (maximum 11, minimum 2) There is no free flagellum in the short and stumpy forms.

From the drawings (Figs. $2,3,4$, and 5) it is abundantly evident that the

Trypanosoma brucei of Zululand 1894 and 1913, of Nyasa-

land, and of Uganda are all

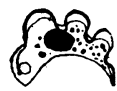

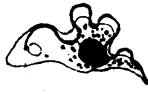<smiles>[CH]1CC[C@H]2C=C[C@H]1CC2</smiles><smiles>O=S(=O)(c1ccccc1)C1CCCC1</smiles>

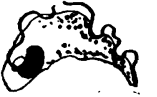
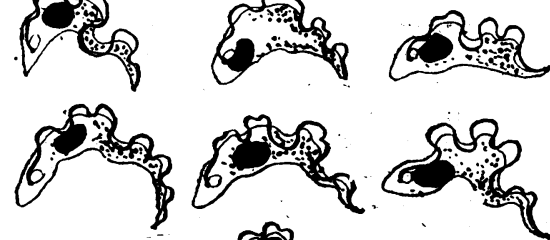
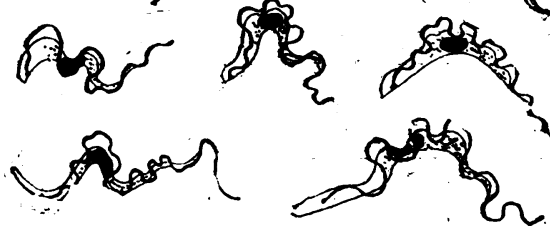

Fig. 5.-Trupanosoma brucei; Üganda. 1908.

identical in morphology. I would especially call attention to the Zululand 1894 drawings. These are taken from the original preparations made in Zululand in that year. An attempt has lately been made to make out that the original nagana parasite was a monomorphic species. These diawings, made from the old preparations, absolutely disprove this.

One useful point in the morphology of these strains lias not yet been mentioned-I mean the length. From Table I ( $p .8)$, which gives the length of various strains of this species, it will be seen that the measurements of trypanosomes, taken from widely separated parts of Africa; come out fairly regularly. The human strain is the longest, having an average length of 24.2 microns, whereas the Zululand 1913 strain is the shortest-21.0 microns. It is rather remarkable that the wild game and the wild Glossina morsitans streins should have resulted in exactly the same measurements.

The breadth of the long and slender arerages 2.76 microns, the intermediate 3.25, and the short and stumpy 3.53 . 
TABLE I.-Giving the Length of the Various Strains of this species.

\begin{tabular}{l|c|c|c|l}
\hline Source of Strain. & Average. & Maximum & Minimum & \multicolumn{1}{|c|}{ Remarks. } \\
\hline Human, Nyasaland & 23.5 & 38.0 & 14.0 & Various, 6,220 \\
Human, Nyasaland & 24.2 & 38.0 & 15.0 & Rats, 3,000 \\
Wild game strain ... & 22.6 & 35.0 & 15.0 & Rats, 2,500 \\
Wild G. morsitans & 22.6 & 35.0 & 15.0 & Rats, 2,500 \\
Zurain & 21.0 & 35.0 & 12.0 & Various, 1,000 \\
Zululand 1913 strain & 22.0 & 35.0 & 13.0 & Various, 200 \\
Uganda 1909 strain & 23.6 & 34.0 & 15.0 & Various, 160
\end{tabular}

Susceptibility of Animals to Trypanosoma Brucei

Having described the motphology of this species and having shown that the various strains found in Uganda, Nyasaland, and Zululand are absolutely identical in appearance, I will pass on to the second part-the pathogenic action of this trypanosome on various animals.

Many mammals, including man, hor'ses, mules, donkeys, oxen, goats, sheep, monkeys, dogs, and many others, are attacked by this parasite. Birds and the cold-blooded vertebrates, such as crocodiles, lizards, and frogs, are quite unaffected by it.

A single trypanosome seems to be just as efficacious in setting up infection as a million, and it does not seem to matter whether the kind of trvpanosome injected is one of the long and slender forms or one of the short and stumpy.

As I have mentioned alreaiy, passage through one species of animal usually heightens its virulence towards that animal. At the Army Medical College, when the nagana trypanosome begins to kill rats in two or three days, it is usual to pass it a ferw times through the rabbit, which has the effect of materially lowering its virulence towards the rat, and making its passaging through the rat less irksome.

In regard to modes of infection, it is extremely easy to infect an animal through the skin; it is usually sufficient to dip a needle in infected blood, and merely to scratcl the skin of the experimental animals. There is evidence also that infection may take place through the mucous membrane; dogs are sometimes infected in this way through eating infected meat, but it is possible that in these cases there is some scratch or wound of the mouth.

Experiments have been published to show that infection can even take place through unbroien skin, but this must be a rare accident, else why have we escaped infection who have made hundreds of post-mortem examinations on cases of sleeping sickness in wan and other animals.

In nagana I think we are safe if we lay down as a rule, that the infection is conveyed in nature, in the vast majority of instances, by the bite of the tsetse fly.

Table II gives the average duration in days of the

Table II.-Giving the Average Duration in Days of the Disease Caused by Various Strains of this Trypanosome.

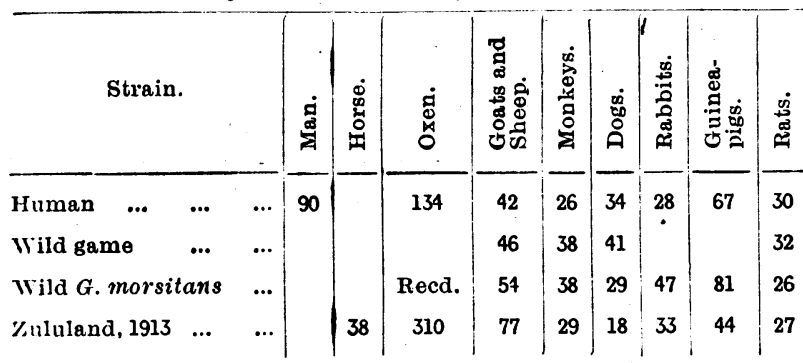

The Number of Animais Employed.

\begin{tabular}{|c|c|c|c|c|c|c|c|c|c|}
\hline IItuman $\quad \ldots$ & $\ldots$ & ... & $?$ & 1 & $?$ & 20 & 25 & 7 & 15 \\
\hline Wild game & ... & ... & & & 5 & 9 & 13 & & \\
\hline Wild G. morsita & & $\ldots$ & & 2 & 16 & 14 & 25 & 3 & 10 \\
\hline Zuiuland, 1913 & $\ldots$ & ... & 3 & 1 & 7 & 8 & 17 & 8 & 10 \\
\hline
\end{tabular}

disease c sused by various strains of this trypanosome, also the number of animals employed. It will be seen that this disease runs a fairly rapid course in man, killing him, as a rule, in three or four months. This, as we shall see, is in marlsed contrast to the much more chronic course of the Congo sleeping sickness caused by. Trypanosoma gambiense. In horses, donkeys, and mules, nagana runs its course on an average in thirty-eight days. No opportunity of studying the disease in horses occurred in Uganda or Nyasaland, as horses are very seldom seen in these countries. In the ox the disease is chronic and a certain proportion recover. In the other animals it may be said broadly that the disease runs a fairly similar course, and that little or no difference in the virulence is seen between the different strains.

Nagana is, as a rule, a fatal disease, and this is shown in Table III, from which it will be seen that no recoveries TABLE III.-Percentage of Recoveries in various Animals infected with T'rypanosoma brucei.

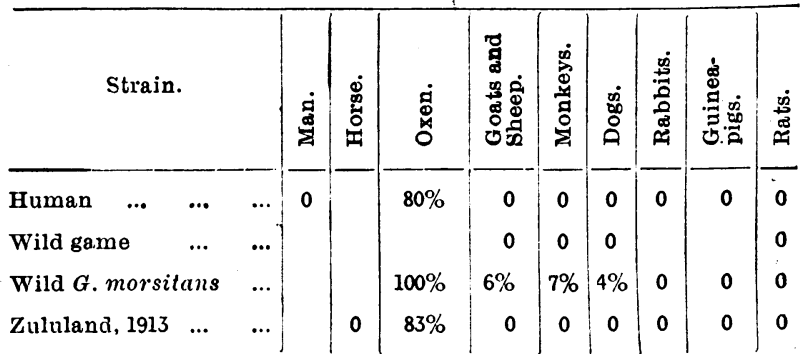

The Number of Animals Employed.

\begin{tabular}{lrrr|l|l|l|r|r|r|r|r|r} 
Human & $\ldots$ & $\ldots$ & $\ldots$ & $?$ & & 5 & 29 & 20 & 25 & 7 & 15 & 21 \\
Wild game & $\ldots$ & $\ldots$ & & & 5 & 9 & 13 & & & 6 \\
Wild G. morsitans & $\ldots$ & & & 2 & 17 & 15 & 26 & 3 & 10 & 19 \\
Zululand, 1913 & $\ldots$ & $\ldots$ & & 6 & 4 & 8 & 17 & 8 & 10 & 23 \\
\hline
\end{tabular}

have been reported up to the present in man. In oxen 80 and 83 per cent. of recoveries are noted. The number of animals employed, however, is so small that these figures are not reliable. With the exception of the oxen almost all the other animals die. Out of 318 employed in these experiments only 3 recovered.

From its action on animals, then, just as from its morphology, it is apparent that Trypanosoma brucei as it occurs in Zululand differs in no way from the Nyasaland strain, called by Stephens and Fantham Trypanosoma rhodesiense. It is true that cases in man have not been reported from Zululand, nor from the Sudan, Uganda, or British East Africa, but I expect this hiatus will be filled up within the next few years.

It is true that Dr. Taute tried to infect himself with Trypanosoma brucei got from the wild game in Portuguese East Africa, and is of opinion that his failure proves that the trypanosome of man and of wild game are different species, but even this does not disturb my belief that the nagana parasite and that causing disease in man in Nyasaland are one and the same. It is of course possible that there may exist in Nyasaland a separate species of trypanosome confined to man and exactly identical in morphology and action on animals with the trypanosome found in the surrounding wild game and the wild fly; it may be possible, I say, but it is highly improbable.

The Carrier of Trypanosoma Brucei.

Having described the morphology of the 'Irypanosoma bruce $i$, and its action on animals, I now come to the question how this protozoon is conveyed from the sick to the healthy. In Zululand, when it became apparent that nagana and tsetse fly disease were identical, experiments were made to find ont if the fly was the carrier of the disease, or merely a concomitant of the low-lying unhealthy country. It was commonly believed by the Zulus that their cattle contracted the disease by drinking out of the same waterholes as the wild game. Healthy horses, therefore, were sent for a few hours into the "fly country," muzzled in such a way that they could neither. eat nor drink while there, but they contracted the disease. On the other hand, bundles of grass and supplies of water brought from the heart of the "fly country," and fed to healthy horses on the top of the hill, failed to infect; but tsetse flies brought up in cages from the low country and placed straightiway on healthy animals were found to give 
rise to the disease. By these and other experiments it was proved beyond question that the tsetse flies, Glossina morsitans and pallidipes, were carriers of nagana, and one of the first questions which presents itself is, What pro. portion of the wild tsetse flies found under natural conditions are infected?

\section{The Infectivity of Wild Tsetse Flies (Glossina} Morsitans).

When in the "fly country," and being bitten by tsetse flies, it is interesting to know how many times one may be bitten without encountering an infected fly.

\section{Methods Employed.}

The method employed in Nyasaland in studying the infectivity of the wild flies was as follows: Native boys were employed in catching the flies in the low country, and these were brought up the same day to the camp in small cages by a native cyclist. Each cage was fed on three hea!thy animals; the first day on a monkey, the second on a dog, and the third day on a goat. To ensure to some extent that each animal was fed on by every fly, the flies were fed daily for nine days, three times on each animal. It is doubtful, however, whether, even with these precautions, every fly did feed on all three animals.

The number of flies in each cage averaged about sixty and as each animal was fed on by three different sets of flies, each monkey, dog, and goat ran the gauntlet of some 180 flies. If any aninal became infected with Trypano soma brucei, it was reckoned that there was only one infective fly in the batch. There may, of course, have been two or more. The method was not very accurate, but probably near enough for practical purposes.

The result is shown in Table IV, and, as will be seen,

TABLE IV.-Proportion of Tsetse Flies (Glossina morsitans) naturally infective wth Trypanosoma brucei, in Nyasaland.

\begin{tabular}{|c|c|c|c|c|c|c|c|c|c|c|}
\hline 1912. & $\begin{array}{l}\text { No of } \\
\text { Flies } \\
\text { Fed. }\end{array}$ & $\begin{array}{l}\text { Mon- } \\
\text { key. }\end{array}$ & Dog. & Goat & 1912 & & $\begin{array}{l}\text { No of } \\
\text { Flies } \\
\text { Fed. }\end{array}$ & $\begin{array}{l}\text { Mon- } \\
\text { key. }\end{array}$ & Dog. & Goat. \\
\hline Jan. 20 & 296 & - & - & + & May & & 190 & & + & \\
\hline $\begin{array}{r}24 \\
\text { " } 29\end{array}$ & 370 & - & & - & " & & 113 & & $\overline{-}$ & \\
\hline Fëb. 29 & $\begin{array}{l}280 \\
295\end{array}$ & $\bar{z}$ & & $\overline{-}$ & $\ddot{~}$ & $\begin{array}{l}29 \\
29\end{array}$ & $\begin{array}{l}120 \\
230\end{array}$ & $\overline{-}$ & $\bar{z}$ & $\bar{z}$ \\
\hline , 9 & 220 & - & & - & ", & 29 & 320 & & + & \\
\hline " 13 & 200 & - & + & $\mp$ & ", & 29 & 240 & - & - & - \\
\hline$\ddot{110} 21$ & 170 & & - & - & "̈ & 31 & 175 & + & + & - \\
\hline ". 26 & 170 & & - & - & June & & 300 & & - & - \\
\hline Mar. 2 & 140 & & - & - & $"$ & 6 & 210 & $\overline{+}$ & I & $\bar{t}$ \\
\hline $\begin{array}{lr}\because \quad & 9\end{array}$ & $\begin{array}{l}165 \\
100\end{array}$ & & $\overline{-}$ & $\overline{-}$ & $\ddot{~}$ & 11 & $\begin{array}{l}230 \\
160\end{array}$ & $\stackrel{+}{-}$ & $\stackrel{+}{-}$ & \pm \\
\hline . 17 & 160 & & - & - & ", & 18 & 135 & - & $\ddot{x}$ & - \\
\hline ". 22 & 205 & & - & + & & 25 & 90 & + & + & - \\
\hline April 3 & 135 & & I & $=$ & July & 3 & 95 & - & - & \\
\hline $\begin{array}{ll}\ddot{10} & 10 \\
.15\end{array}$ & $\begin{array}{l}275 \\
330\end{array}$ & $\stackrel{+}{-}$ & \pm & $=$ & $\begin{array}{c}\text { Sept. } \\
\text {,. }\end{array}$ & $\begin{array}{l}25 \\
27\end{array}$ & $\begin{array}{l}70 \\
25\end{array}$ & $\bar{t}$ & & \\
\hline ". 18 & 200 & - & - . & - & Oct. & 29 & 87 & + & + & + \\
\hline 18 & 180 & - & - & - & Nov. & 5 & 145 & & - & \\
\hline & 230 & $=$ & $\overline{-}$ & - & ". & 11 & 150 & $\overline{-}$ & $\overline{-}$ & $\bar{z}$ \\
\hline 23 & 140 & $\overline{-}$ & $=$ & $\overline{5}$ & $"$ & 18 & 157 & $\overline{-}$ & $\bar{t}$ & $\bar{t}$ \\
\hline$\because \quad 27$ & 260 & _ & - & - & $\ddot{\prime \prime}$ & 25 & 180 & - & + & + \\
\hline Mäy 3 & 155 & + & - & - & Dëc. & 3 & 180 & - & - & \\
\hline & 370 & $\bar{t}$ & $\bar{t}$ & - & " & 6 & 198 & \pm & + & $\stackrel{+}{+}$ \\
\hline 8 & 330 & + & t & $=$ & 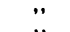 & 11 & 155 & $\overline{-}$ & \pm & + \\
\hline " $\quad 9$ & $\begin{array}{r}120 \\
50\end{array}$ & $=$ & $\vec{t}$ & $=$ & & 16 & 110 & - & & - \\
\hline 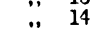 & 250 & - & - & + & Total & & 10.081 & 9 & 14 & 11 \\
\hline
\end{tabular}

there were 56 experiments, in which 10,081 tsetse flies (Glossina morsitans) were employed. In the 56 experiments Trypanosoma brucei was found 20 times (35.7 per cent.); 9 monkeys, 14 dogs, and 11 goats were infected. This gives a proportion of 1 in 500 or 2 flies per 1,000 caught in the sleeping-sickness area, Nyasaland, infective with nagana. This is only allowing one infective fly to each series of flies fed on the experimental animals, and is therefore the irreducible minimum.

Months and Seasons.

From these experiments it is also seen that these infective flies occur all the year round, and are just as numerous during one season as another.

To conclude, then, in regard to the natural infectivity of Glossina morsitans with this species of trypanosome, it may be said that if a man is bitten by a tsetse fly in the sleeping sickness area of Nyasaland, it is 500 to 1 against his taking the disease, since only 1 in every 500 flies is infective with the specific parasite.
Cycle of Development.

I ought now to describe the cycle of development of the nagana parasite in the tsetse fly, but as this development is identically the same as that of Trypanosoma gambiense in Glossina palpalis, and as the cycle was first worked out by us with the latter, it will be better to defer the description of this cyclical development until we come to discuss Trypanosoma gambiense. I shall therefore now pass on to consider the reservoir in order to answer tho question, Whence does the tsetse fly obtain the nagana virus?

The Reservoir.

In Zululand in 1896, when it became certain that nagana or tsetse fly disease was conveyed to the animals by the fly, the question arose as to where the fly obtained the virus. In the Zululand fly country there were no natives, since cattle could not live there, and with the Zulus cattlo stand for everything. There were therefore no horses, oxen, goats, or dogs suffering from nagana from which the fly could obtain the parasite.

But the place being a Government Reserve, was swarm. ing with wild animals on which it was evident the fly fed. If one of these animals was shot in the "fly country," many tsetses would often be found still feeding on the dead body. This led to the examination of the buffalo, koodoo, wildebeeste, and other wild game found in tho district. As soon as an animal was killed a quantity of its blood was sent off, by a native runner, to the top of the hill, where it was injected into a healthy dog. Smears were also made and examined microscopically. In this way it was proved both by animal experimentation and direct microscopical examination that the blood of many of these wild animals contained the same trypanosome as that which gave rise to nagana. The mystery of the reservoir was cleared up.

Since 1896 further observations have been made regarding the presence of these parasites in the blood of wild game in different parts of Africa-on the West Coast, in Uganda, and notably in North-Eastern Rhodesia by Kinghorn and Yorke. In Nyasaland we also examined the wild game with some care, and I shall now proceed to describe the results.

Trypanosomes found in the Blood of Wild Animals Living in the Sleeping Sickness Area, Nyasaland.

The method of examining the blood of wild game was much the same as that used in Zululand. When an animal was shot a small quantity of its blood was taken in a sterilized bottle containing potassium citrate to prevent coagulation. Smear preparations were made at the same time. As the animals were often shot thirty or forty miles away from the camp, a motor cycle was used to get the blood up the hill as quickly as possible. When the blood arrived at the laboratory it was at once injected into a goat, a monkey, and a dog. In this way 180 specimens of blood of wild game living in the fly area were examined, and 57 were found to harbour pathogenic trypanosomes (32 per cent.).

This is, however, probably much below the actual percentage. A wild animal is only examined once, and that often under unfavourable conditions. If it were possible to examine the same animal several times it is probable that many more would be found infected. The parasites come and go in the blood, one day they may be present the next day absent. The big game live in the " $\mathrm{fly}$ country" among swarms of infected flies and are con. stantly liable to infection and reinfection.

Table V (p. 10) records the number of times Trypanosoma bruce $i$ was found among the 180 wild animals examined, and the species of 'game which harboured it. It will be seen that fourteen animals among the 180 harboured the nagana parasite $(7.8$ per cent.), and that the waterbuck, hartebeeste, reedbuck, and duiker ssem to be the most dangerous neighbour's to man, for 23 per cent. of the waterbuck, 14 per cent. of the hartebeestes, 16 per cent. of the reedbuck, and 14 per cent. of the duiker had Trypanosoma brucei in their blood. If, then, my conten. tion that this parasite found in the wild game is the causs of Nyasaland sleeping sickness be proved to be true, then it is abundantly obvious how dangerous these wild animals are to man; and it must be borne in mind that in this Nyasa'a 1 d fly area Trypanosoma brucei is only one of the pathogenic species of trypanosome found in the wild game. 
TaBr.s V.-Shouing the Number of Times Trypanosoma brucei cas found among the 180 Wild Amimals E.ramined and the species of Game which Harboured it.

\begin{tabular}{|c|c|c|c|c|c|}
\hline $\begin{array}{l}\text { Species of } \\
\text { Animal. }\end{array}$ & $\begin{array}{c}\text { Number } \\
\text { Examined. }\end{array}$ & $\begin{array}{l}\text { Number } \\
\text { Infected } \\
\text { with } \\
\text { T. brucei. }\end{array}$ & $\begin{array}{l}\text { Species of } \\
\text { Animal. }\end{array}$ & $\begin{array}{l}\text { Number } \\
\text { Examined. }\end{array}$ & $\begin{array}{l}\text { Number } \\
\text { Infected } \\
\text { with } \\
\text { T. brucei. }\end{array}$ \\
\hline Eland $\quad \ldots$ & 10 & 0 & Duiker ... & 7 & 1 \\
\hline Sable $\quad \ldots$ & 5 & 0 & Buffalo ... & 9 & 0 \\
\hline Waterbuck & 13 & 3 & Lion $\quad \ldots$ & 1 & 0 \\
\hline Kcodoo ... & 3 & 0 & Hyaena... & 3 & 0 \\
\hline Bushbuck & 10 & 0 & Elephant & 2 & 0 \\
\hline Hartebeeste & 35 & 5 & Warthog & 33 & 1 \\
\hline Rezdbuck & 19 & 3 & Wild cat & 3 & 0 \\
\hline Oribi & 26 & 1 & Porcupine & 1 & 0 \\
\hline
\end{tabular}

Three other species pathogenic to the domestic animals are also found-Trypanosoma pecorum, T'rypanosoma simiae, and Trypanosoma caprae-Trypanosoma pecorum in 14.4 per cent.; Trypanosoma simiae in 1.7 per cent.; and Trypanosoma caprae in 11.1 per cent. of the wild game examined; therefore I do not think I was using too strong language when $I$ wrote in a report to the Royal Society :

It is salf-evident that these wild animals should not be allowed to live in "Hly country," where they constitute a standing danger to the native inhabitants and the domestic animals. It would be as reasonable to allow mad dogs to live and be protected by law in our English towns and villages. Not only should all game laws restricting their destruction in "fly only should all game laws restricting their destruction in " fly country" be removed, but active mea
their early and complete blotting out.

It must be strictly borne in mind that this only refers to wild animals living in "fly" areas. No pathogenic trypanosomes have up to the present been found by the Commission in the blood of animals living in fly-free areas.

\section{NERVE SUTURE FOR BULLET WOUNDS.} BY

R. ATKINSON STONEY, F.R.C.S.I. SURGEON TO THE ROYAL CítY OF DUBLIN hOSPITAL AND

H. MEADE, F.R.C.S.I.,

ASSISTANT SURGEON TO ST. VINCENT'S HOSPITAL, DUBLIN.

WHILE acting as consulting and operating surgeons to the French army during the last six montlis, we had many opportunities of seeing cases of nerve injury caused by modern weapons, and we performed several operations for their relief. In only two cases, howerer, were the patients under our observation for a sufficient length of time to allow us to judge the results of these operations. The following is a short account of these two cases :

CASE I.-Bullet Wound of Ulnar Nerve.

A. P., a soldier wounded at the Marne by a rifle bullet, A. P., a soldier wounded at the Marne by a rifle bullet,
September 7 th, 1914, was seen by us in December. He then September $7 \mathrm{th}, 1914$, was seen by us in December. He then side of the left forearm, about 2 in. below the elbow; the $x$ rays showed a united fracture of the ulna with several sequestra and small pieces of metal, probably pieces of the mantle of the bullet. There was complete loss of function of the ulnar nerve paralysis of the muscles with claw-contraction of the three inner fingers, and loss of sensation of the ulnar side of the hand and inner two fingers back and front.

An operation was performed on December 18th for the removal of the sequestra and pieces of metal, after which the wounds healed rapidly.

On January 19th, 1915, a vertical incision was made over the course of the ulnar nerve for about 4 in., the nerve was exposed above and below the seat of injury, and then tract exposed above and below the seat of injury, and then traced between the two segments of the nerve, but in the region of the wound there was a large, somewhat oval mass of tissue, almost wound there was a large, somewhat oval mass of tissue, almost was greatly wasted. It was necessary to remove nearly 1 in. was greatly wasted. It was necessary to remove nearly 1 in. of tissue before nerve tibres could be found on the cut surface
of either end. In spite of freeing the proximal end of the nerve up to the interual condyle and the distal end for several inches, and flexing the wrist and fingers, it was found impossible to bring the cut ends into contact, and they were finally sutured together, leaving a gap of about 1 centimetre between them.
Two relaxation sutures of No. 1 silk were passed at some clis tance from the cut ends, which were then sutured with No. and No. 0 silk; altogether there were over a dozen strands of silk bridging the gap between the two ends of the nerve.

The operation wound healed normally, and the flexion of the wrist and fingers was gradually reduced after the first fortnight massage, movements, and electrical stimulation (both faradic and galvanic) were then started and continued until the patient's discharge from the hospital early in May.

Within two months of the operation there was good voluntary power of contraction of the flexor carpi ulnaris, and on rolling the ulnar nerve under the finger between the intermal condyle and olecranon a tingling sensation was felt down to the base of the little finger ber the little finger; before operation this sensation had only been felt down to the level of the wound. From this time on pital, about $3 \frac{1}{2}$ months after the operation, motor porver liad pitar, about $3 \frac{1}{2}$ months after the operation, motor power hac fundus digitorum (shown by his better power of flexion of the fundus digitorum (shown by his better power of flexion of the phalanges), there was commencing response of the intrinsic
muscles of the hand to faradic stimulation over the course of muscles of the hand to faradic stimulation over the course of the exception of the little finger, though tingling could be fel to the tip of this finger on stimulation of the nerve above the point of suture. The characteristic deformity of the hand hac almost entirely disappeared.

Between the time of injury and the operation the patient stated that there had been no change in the condition of his forearm and hand, and during the month be was under our observation between the two operations there was no change, except a slight increase in the deformity, although he was except a slight increase in the deformity, alth
daily receiving massage and electrical treatment.

CASE II.-Bullet Wound of Musculo-spiral Nerve.

B. D., a sotdlier, was first seen by us on December 28 th, 1914 $\mathrm{He}$ had been wounded by a rifle bullet on the outside of the right arm, just above the elbow, about a fortnight before. $\mathrm{He}$ was treated at a hospital close to the front. While there he had, about five days after he was wounded, a severe haemorrhage, for which an operation was performed to stop the bleeding, and at the same time the musculo-spiral nerve was sutured. Whether the nerve had been divided by the bullet or was cut during the operation we were never able to discover.

When the patient came under our care he hall a large oblique incision, nearly healed, running upwards, outwards, and backincision, nearly healed, running upwards, outwards, and backwards for about $4 \mathrm{in}$. from the outer part of the front of the
elbow. There was complete loss of power of the extensor elbow. There was complete loss of power of the extensor muscles of the wrist and fingers, and loss of sensation over the
area of distribution of the radial nerve. He was treated by
massage, movements, and electricity (both faradic and galmassage, movements, and electricity (both faradic and gal-
vanic). At the end of two months sensation was commencius vanic). At the end of two months sensation was commenciugs
to return, and at the end of April he was transferred to a special.hospital for mechanotherapy. Sensation was then normal, and he was able to raise the hand when prone fron the fully flexed position to the straight position. Power of

The improvement in this case was not so marked as in the other, but this may be explained probably by the fact that the patient did not seem to take so great an intercst in his own treatment and cure, and therefore made less voluntary effort to recover the lost movements.

In only one case did we have an opportunity of suturing a nerve at an early stage after injury.

CASE III.-Bullet Wound of Ulnar Nerve.

Soldier, wounded March 23rd, 1915, by a rifle bullet which passed through the inner side of the right forearm just below the middle, fracturing the ulna. On admission to hospital, three days later, there was loss of sensation of the little finger back and front, with paralysis of the intrinsic muscles of the back and front, with paralysis of the intrinsic muscles of the hand supplied by the ulnar nerve. As the loss of sensation was only partial we hoped that the nerve was only slightly injured and that recovery would be rapid, and massas

treatment were commenced after a few days.
At the end of three weeks the condition was in no way improved and well-marked contraction had commenced in the three inner fingers. On April 14th, therefore, an incision was made and the nerve exposed in the region of the wound, whicl had healed. It was found that about three-quarters of the nerve trunk had been divided and that the cut ends were considerably separated and turned backwards into the muscles. There was a great deal of soft granulation tissue surrounding the injured portion of the nerve, which would in time have formed the very dense, hard, fibrous tissue we found in all the cases operated on at a late period after injury. The cut ends were freed and sutured together with silk without interfering with the undivided portion of the nerve. When this patient was last seen, about six weeks after operation, there was no appreciable seen, about six weeks after
change in his condition.

In another case only a portion of the nerve was divicled, but it did not come under our care till several months after the injury.

CASE IV.-Bullet Wound of External Popliteal Nerve.

A soldier was wounded in the right knee in August, 1914, by a and fractured the femur. 